\title{
Experimental Viral Hepatitis in the Dog: Production of Persistent Disease in Partially Immune Animals *
}

\author{
D. J. Gocke, R. Preisig, T. Q. Morris, D. G. McKay, and S. E. Bradley \\ (From the Departments of Medicine and Pathology, Columbia University College of Physicians \\ and Surgeons, New York)
}

\begin{abstract}
Experimental infection with canine hepatitis virus has been studied in a series of 49 dogs. The pattern of response to infection was distinctly modified by the immune status of the animal. All of 19 fully susceptible dogs had an acute, fulminating fatal hepatitis when infected with a standard dose of virus, and all of $19 \mathrm{dogs}$ with high levels of immunity to the virus survived without apparent illness. However, $11 \mathrm{dogs}$ were spontaneously encountered with partial immunity to the infectious agent, and these animals developed different, prolonged forms of hepatitis following infection. In four animals death occurred in 8-21 days following what may be called a subacute course. The remaining seven dogs survived up to 8 months with evidence of chronic hepatic damage. The subacute and chronic forms of hepatitis were reproduced experimentally in seven of eight fully susceptible dogs which were passively immunized against the canine hepatitis virus by administration of hyperimmune serum. Although the virus could be found in sites of hepatic damage in the early stages of the subacute and chronic diseases, it could not be demonstrated in the later stages which were characterized by persistent hepatic damage and a marked chronic inflammatory reaction. Dogs with chronic hepatitis eventually developed extensive hepatic fibrosis. The pathologic, physiologic, virologic, and immunologic features of these experimental forms of viral hepatitis are described.
\end{abstract}

\section{Introduction}

The study of viral hepatitis in man is seriously limited by the long-standing difficulties in isolating the etiologic agent in vitro and in reproducing the disease in animals. Canine hepatitis, however, is a viral disease of the liver which produces striking hepatic damage in dogs and which has the experimental advantage of being caused by a cultivatable adenovirus. Viral hepatitis is widespread in the canine population and is a common cause of death. The disease was originally described in 1947 by Rubarth (1), who established the viral

* Submitted for publication 9 January 1967; accepted 7 June 1967.

This study was supported by a grant from the John A. Hartford Foundation, Inc.

Address requests for reprints to Dr. David J. Gocke, Department of Medicine, College of Physicians and Surgeons, 630 West 168th Street, New York, N. Y. 10032. etiology and demonstrated the pathologic findings in dogs dying of the disease. In 1954 Cabasso and his coworkers (2) reported the successful propagation of the canine hepatitis virus in vitro. This led to attenuation of the virus in tissue culture and made possible the development of an effective live virus vaccine $(3-5)$. Subsequent investigation has shown the canine hepatitis virus to be an adenovirus which has partial antigenic cross-reactivity with human adenoviruses, but which is not known to produce disease in man $(6,7)$. Current knowledge concerning this virus has been reviewed by Cabasso (8).

The ability to isolate and grow the causative agent of canine hepatitis in vitro makes it possible to carry out the type of controlled experiment in the dog which cannot be done at the present time in man. Thus, the canine disease has been employed in this laboratory as a convenient model 
for the experimental study of viral infection of the liver, and the correlation of pathologic and virologic events with alterations in hepatic function. In the course of this study, it became apparent that the pattern of response to experimental infection was distinctly modified by the immune status of the animal. More specifically, a syndrome of chronic progressive hepatic damage has been observed in dogs which were only partially immune to the virus. In addition, it has been possible to reproduce such chronic liver disease in susceptible dogs by passive immunization to the canine hepatitis virus. These observations are the subject of this report.

\section{Methods}

The animals used in these studies were young purebred beagles, 12-20 wk old, obtained from the Cyn-Piera Kennels. ${ }^{1}$ The dogs were born and raised in an isolated environment in order to avoid natural infection with canine hepatitis virus. Approximately 1 month before study, they were immunized against distemper with an attenuated live virus vaccine (Tissuevax, Pitman-Moore Co., Indianapolis, Ind.), and against leptospirosis with a standard heat-killed Leptospiral antigen (Leptospira Bacterin, Pitman-Moore). The animals were transported by air to this laboratory, subjected to control studies, and then infected within $12 \mathrm{hr}$ after removal from isolation. The following studies were carried out before infection, daily during the early acute phase, and then less frequently during the latter phases. The weight, rectal temperature, and general condition of the animal were noted. Biopsies of the liver were obtained with a Menghini needle for histologic and fluorescent antibody studies. The serum was examined for the presence of virus and antiviral antibody in a tissue culture system (see below). The white blood cell count, hematocrit, serum alkaline phosphatase, serum glutamic oxaloacetic transaminase (SGOT), and the serum glutamic pyruvic transaminase (SGPT) were determined by standard methods. Studies of bromsulphalein transport maximum (BSP $\mathrm{Tm}$ ) and storage $(S)$ were measured by the dual infusion technique (9). The dogs usually were infected by inoculation of $300 \mathrm{TCID}_{\mathrm{so}}$ of canine hepatitis virus into the anterior chamber of the eye. In a few animals the virus was administered by the subcutaneous route (see Results).

Virologic techniques. Canine hepatitis virus was originally supplied by Dr. Victor J. Cabasso (Lederle Laboratories, Pearl River, N. Y.) as a $20 \%$ suspension of crude liver homogenate from an infected dog. Subsequently, other infective liver homogenates were prepared from dogs dying with fulminating hepatitis. The infected liver tissue was finely minced and subjected to repeated freezing and thawing. Cellular debris and fibrous tissue were

\footnotetext{
1 Cyn-Piera, Inc., Freeville, N. Y.
}

centrifuged and filtered out, and the crude homogenates were stored in the lyophilized state at minus $70^{\circ} \mathrm{C}$.

Primary cultures of canine kidney were prepared by the method of Bodian (10), or obtained from commercial sources. ${ }^{2}$ The growth medium was the minimum essential medium of Eagle (Microbiological Associates, Inc.) supplemented with $10 \%$ fetal calf serum (Grand Island Biological Co., Grand Island, N. Y.) heated at $56^{\circ} \mathrm{C}$ for $30 \mathrm{~min}$, penicillin $100 \mu \mathrm{g} / \mathrm{ml}$, and streptomycin $100 \mu \mathrm{g} / \mathrm{ml}$. For maintenance, the serum concentration was reduced to $1 \%$. Virus titrations were carried out by the tube technique under the conditions recommended for this system by Carmichael et al. (11). Titers were expressed in TCID so as determined by the Karber method (12). Neutralizing antibody to the canine hepatitis virus in serum was determined in a standard tissue culture neutralization assay, with $100 \mathrm{TCID}_{\mathbf{5 0}}$ of the virus as the test dose. Results were expressed in terms of the dilution of serum giving $50 \%$ neutralization of the cytopathic effect.

Fluorescent antibody techniques. Sera containing high titers of neutralizing antibody were conjugated with fluorescein diisothiocyanate by the method of Rinderknecht (13). To minimize nonspecific staining, we passed the conjugated antisera through a $10 \times 2 \mathrm{~cm}$ column of G25 Sephadex, and absorbed them 4 times with $10 \mathrm{mg}$ of acetone-dried liver powder per $\mathrm{ml}$ of serum. Needle biopsy specimens of the liver were rapidly frozen on dry ice. Sections were cut at $3 \mu$ in an International microtome cryostat and fixed in acetone for $15 \mathrm{~min}$, and fluorescein-conjugated antiserum was applied for $60 \mathrm{~min}$ at $37^{\circ} \mathrm{C}$ in a humid chamber. The specimens were washed 3 times with phosphate-buffered saline ( $\mathrm{pH} 7.2)$, and examined microscopically for specific fluorescence using ultraviolet illumination and the darkfield technique. Specificity of the fluorescence for canine hepatitis virus was established by the following control procedures: $(a)$ pretreatment of frozen sections of infected liver with unconjugated antiserum (followed by fluorescein-conjugated antiserum) resulted in blocking of the specific fluorescence; $(b)$ infected liver exposed to fluoresceinconjugated normal dog serum (i.e., without antibody to the virus) failed to show specific fluorescence; $(c)$ normal liver treated with the labeled antiserum showed no fluorescence; $(d)$ tissue culture cells infected with canine hepatitis virus showed characteristic fluorescence when stained with labeled antiserum.

\section{Results}

\section{I) Experimental Production of Disease}

Observations in 49 dogs experimentally infected with canine hepatitis virus are summarized in Table I. Three patterns of response were seen: early death, survival with evidence of hepatic dis-

\footnotetext{
2 Microbiological Associates, Inc., Bethesda, Md. and Baltimore Biological Laboratories, Baltimore, Md.
} 
TABLE I

Summary of disease patterns after experimental infection with canine hepatitis virus

\begin{tabular}{|c|c|c|c|c|c|}
\hline Group & $\begin{array}{l}\text { No. } \\
\text { of } \\
\text { dogs }\end{array}$ & Course & $\begin{array}{l}\text { Titer of antiviral } \\
\text { antibody* }\end{array}$ & Hepatic pathology & $\begin{array}{l}\text { Staining with } \\
\text { fluorescent } \\
\text { antiviral } \\
\text { antibody }\end{array}$ \\
\hline $\mathrm{A}$ & 19 & Death, day 4-9 & $<1 / 4$ & $\begin{array}{l}\text { Massive hepatic necrosis } \\
\text { with INI }\end{array}$ & Positive \\
\hline $\mathrm{B}$ & & Well, day $4-8$ & $\geqq 1 / 16 \leqq 1 / 500$ & Focal necrosis with INI & Positive \\
\hline 1) & 4 & Death, day 8-21 & & $\begin{array}{l}\text { Extensive hepatic } \\
\text { necrosis with lymphocytes } \\
\text { + plasma cells, no INI }\end{array}$ & Negative \\
\hline 2) & 7 & Survival, to $8 \mathrm{mos}$. & & $\begin{array}{l}\text { Chronic inflammation } \\
\text { and fibrosis }\end{array}$ & Negative \\
\hline $\mathrm{C}$ & 19 & Well (all dogs) & $\geqq 1 / 500$ & Normal & Negative \\
\hline
\end{tabular}

*Values given are titers on the day of infection, except for certain Group B animals in which antibody first appeared 4-5 days after infection (see text and Table II).

$\ddagger$ INI, Intranculear inclusion body of the canine hepatitis virus.

ease, or survival without apparent illness. In general, the response correlated with the animal's level of immunity to the virus.

\section{A) Acute disease in the fully susceptible dog}

In 19 dogs (Group A, Tables I and II) the disease was an acute, fulminating illness leading to death in 4-9 days after infection. An example of the course of the disease in such a dog can be seen in Lydia. The dog appeared well for the first 3-4 days, except for slight temperature elevation $\left(103.5^{\circ} \mathrm{F}\right)$ and development of corneal opacification in the infected eye. On the 5th day, viremia appeared, the temperature rose further

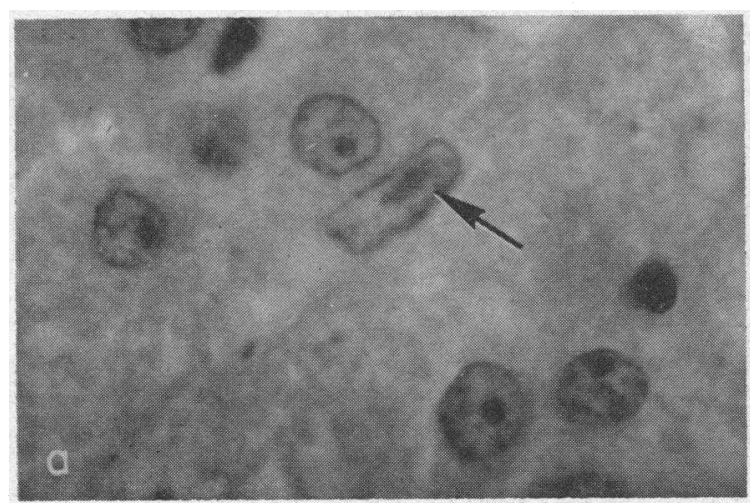

to $105^{\circ} \mathrm{F}$, and hepatic dysfunction was first evident in depression of BSP Tm (70\% of control). By the 6th day, the animal was noticeably lethargic and anorectic, the SGOT was now definitely elevated (95 Karmen units), and both BSP S and $\mathrm{Tm}$ were reduced ( 80 and $65 \%$ of control, respectively). Thereafter, the disease process seemed to explode, and within $12 \mathrm{hr}$ the dog expired before further studies could be carried out. Neutralizing antiviral antibody was not found in detectable amounts $\left(<\frac{1}{4}\right)$ before or during the illness.

The earliest abnormality recognized in the liver of this $\operatorname{dog}$ was found on day 5 at the time when

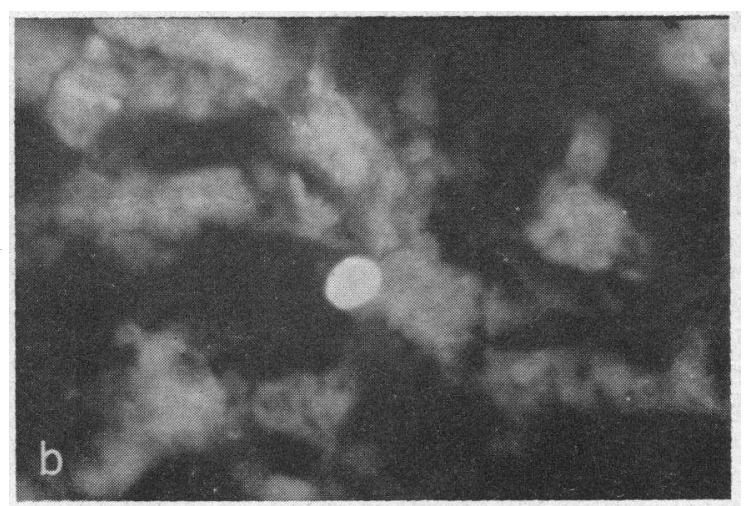

Fig. 1. HePATIC biOPSY FROM Lydia ON THE 5TH DAY AFTER INFECTION WHEN Histologic ABNORMALITIES WERE FIRST RECOGNIZED. (a) Hematoxylin- and eosin-stained section showing an intranuclear inclusion body typical of the canine hepatitis virus in a Kupffer cell. $\times 1000$. (b) Frozen section stained with fluorescein-labeled antiserum to the canine hepatitis virus showing one of the brightly fluorescent bodies found along the hepatic sinusoids. $\times 400$. 

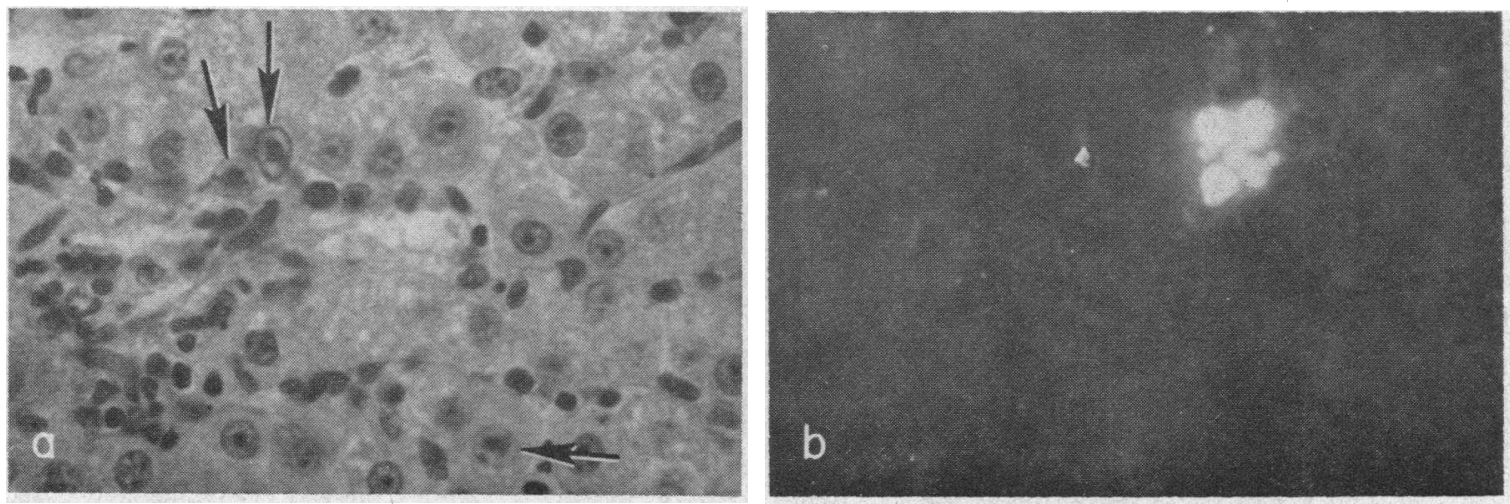

Fig. 2. Hepatic biopsy from Lydia on DAy 6 AfTER infeCtion. (a) A small focus of hepatic necrosis with several cells containing typical intranuclear inclusions (arrows). Hematoxylin and eosin, $\times 400$. (b) Frozen section stained with fluorescent antiviral antiserum showing a cluster of fluorescent viral material in a necrotic focus. $\times 400$.

viremia was first detected. A diffuse increase in inflammatory cells in the hepatic sinusoids and the appearance of characteristic intranuclear inclusion bodies of the canine hepatitis virus, predominantly in Kupffer cells, were observed (Fig. $1 a)$. The presence of viral antigen in these cells was demonstrated in frozen sections of the liver stained with fluorescein-labeled antiviral antibody (Fig. $1 b$ ). By day 6 , the liver was studded with small foci of parenchymal necrosis containing typical intranuclear inclusion bodies (Fig. $2 a$ ). Small clusters of viral material were seen in these foci on staining with fluorescent antibody (Fig. $2 b$ ). Finally, when examined at autopsy $12 \mathrm{hr}$ later, severe hepatic necrosis (Fig. $3 a$ and $c$ ) and widespread fluorescent staining (Fig. $3 b$ ) were found, with intranuclear inclusions in almost every cell.

The disease pattern observed in all 19 of the acute animals was similar to that described above for Lydia. Table II summarizes clinical, biochemical, and serologic observations in the entire group of animals. The acute disease was characterized by development of fever and dense corneal opacification in the infected eye, followed by the onset of lethargy, anorexia, and abnormalities in serum alkaline phosphatase and SGOT, and then rapid deterioration to coma and death in a matter of hours. All of these dogs had severe hepatic necrosis on autopsy. The disease progressed so quickly that the severity of hepatic damage at death was not always reflected in biochemical values obtained only $24 \mathrm{hr}$ before. Dogs such as
Vem and Willy (Table II) in which blood was obtained only $2-3 \mathrm{hr}$ before death had marked elevations of SGOT and alkaline phosphatase. Measurement of other clinical and chemical parameters commonly employed in the study of human liver disease were not found to be useful because the fulminant course did not allow significant changes to be observed. Significant elevation of serum bilirubin was rarely observed because of the high renal clearance of bile pigments in the dog.

It was possible to carry out detailed studies of BSP kinetics during the course of acute hepatitis in 11 puppies. Each animal served as its own control. Control values for $\mathrm{S}$ ranged from 10.8 to $14 \mathrm{mg} / \mathrm{mg} \%$ (averaged 12.8, sD 1.18 ), and for $\mathrm{Tm}$ from 2.4 to $3.2 \mathrm{mg} / \mathrm{min}$ (average 2.9 , SD $0.26)$. After infection, a depression in one or both values was observed as early as day 2 in two animals. By the 4th day after infection, both $\mathrm{S}$ and $\mathrm{Tm}$ were usually decreased (average $65 \%$ of control) in the nine animals studied at that time. Elevations in the SGOT and serum alkaline phosphatase were always associated with changes in BSP kinetics, and in two animals a depression of $\mathrm{Tm}$ and $\mathrm{S}$ preceded enzymatic abnormalities.

It is emphasized that none of the dogs with acute disease had detectable antibody to the virus at the time of infection nor did they develop antibody during the brief course of their illness. These animals appeared to have been fully susceptible and were overwhelmed by the virus before an immune response could occur. Viremia was observed as early as the 2 nd day after infection in 

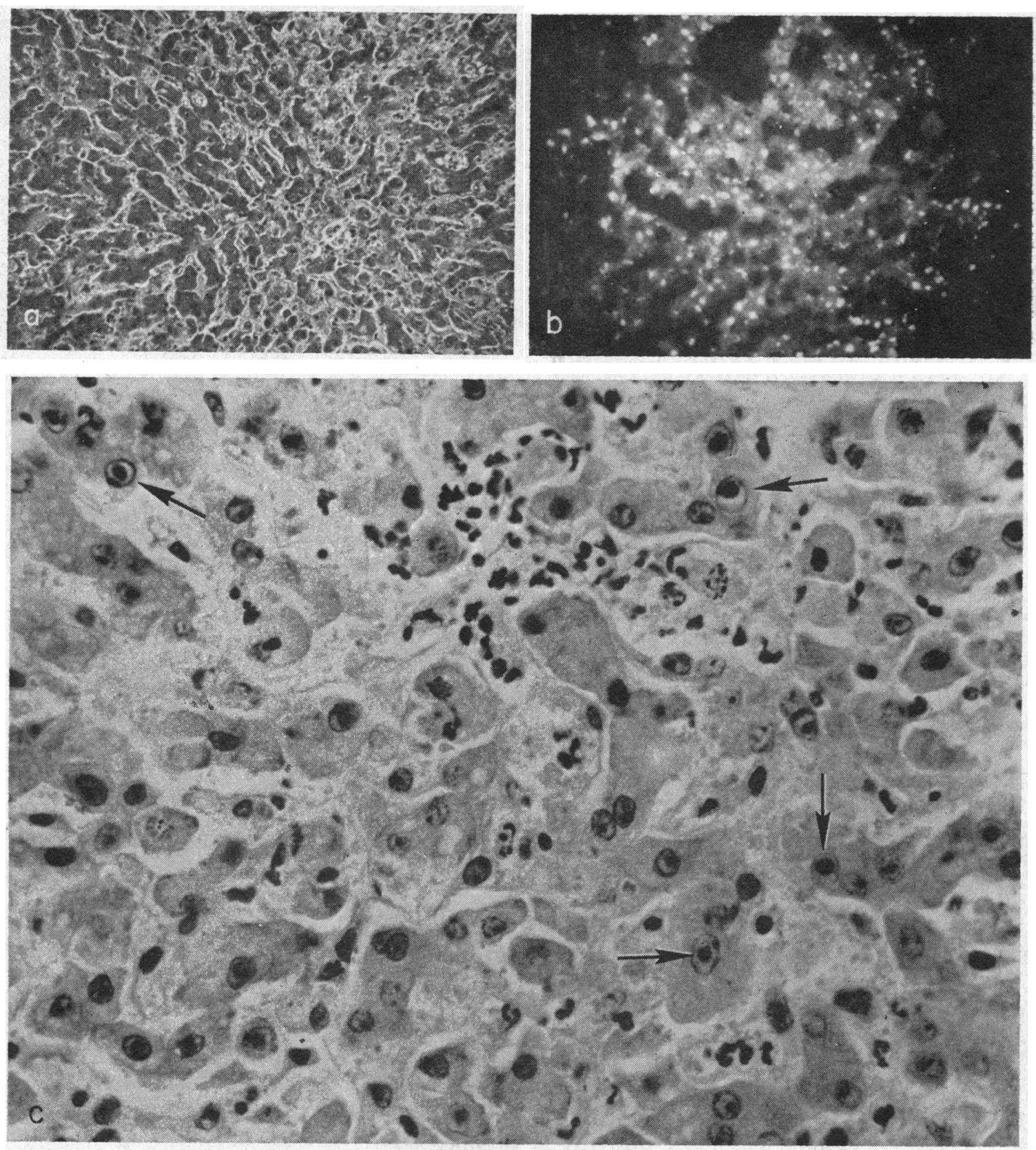

Fig. 3. Findings at autopsy on Lydia who died between day 6 and 7 after infection. (a) Hematoxylin and eosin section of liver showing extensive hepatic damage. $\times 160$. (b) Frozen section stained with fluorescent antiviral antiserum showing widespread fluorescent staining. $\times 100$. (c) Higher magnification showing disruption of hepatic cords, cells in varying stages of necrosis, and multiple intranuclear inclusions (arrows). Hematoxylin and eosin, $\times 400$.

some cases, while in others it was not detected until the 4 th or 5 th day. The onset of viremia was accompanied by the finding of virus in the reticuloendothelial system of the liver. Once this point was reached the animal usually died within $48 \mathrm{hr}$ with extensive hepatic necrosis and abundant, easily demonstrable virus in the liver. It is to be reemphasized that none of the 19 dogs that died of 
TABLE II

Summary of clinical, biochemical, and serologic observations in canine hepatitis

\begin{tabular}{|c|c|c|c|c|c|c|}
\hline \multirow[b]{2}{*}{ Dog } & \multirow[b]{2}{*}{ Course } & \multirow{2}{*}{$\begin{array}{c}\text { Alk. phos- } \\
\text { phatase* } \\
\text { (KAU) } \ddagger\end{array}$} & \multirow{2}{*}{$\underset{(\mathrm{KU}) \&}{\text { SGOT* }}$} & \multicolumn{2}{|c|}{ BSP* } & \multirow[b]{2}{*}{ Titer antiviral antibody $\mathbb{T}$} \\
\hline & & & & $\operatorname{Tm} \|$ & $\mathbf{S} \|$ & \\
\hline & & & & $m g / m i n$ & $m g / m g \%$ & \\
\hline \multicolumn{7}{|c|}{ Acute disease, Group A } \\
\hline $\begin{array}{l}\text { Aaron } \\
\text { Boris } \\
\text { Eli } \\
\text { Favia } \\
\text { Gideon } \\
\text { Herod } \\
\text { Isis } \\
\text { Job } \\
\text { Lydia } \\
\text { Moses** } \\
\text { Noah** } \\
\text { Nick } \\
\text { Selma } \\
\text { Vem } \\
\text { Willy } \\
\text { Eros } \\
\text { Fairy } \\
\text { Illya } \\
\text { Moreen }\end{array}$ & $\begin{array}{ll}\text { Death day } & 5 \\
\text { Death day } & 5 \\
\text { Death day } & 6 \\
\text { Death day } & 4 \\
\text { Death day } & 4 \\
\text { Death day } & 4 \\
\text { Death day } & 6 \\
\text { Death day } & 4 \\
\text { Death day } & 7 \\
\text { Death day } & 6 \\
\text { Death day } & 9 \\
\text { Death day } & 4 \\
\text { Death day } & 6 \\
\text { Death day } & 5 \\
\text { Death day } & 5 \\
\text { Death day } & 6 \\
\text { Death day } & 6 \\
\text { Death day } & 6 \\
\text { Death day } & 5\end{array}$ & $\begin{array}{r}16 \\
22 \\
14 \\
16 \\
13 \\
8 \\
13 \\
35 \\
46 \\
43 \\
35 \\
14 \\
50 \\
34 \\
- \\
17 \\
-\end{array}$ & $\begin{array}{r}85 \\
85 \\
360 \\
85 \\
100 \\
78 \\
120 \\
- \\
95 \\
380 \\
130 \\
800 \\
63 \\
1000 \\
1500 \\
- \\
- \\
650 \\
-\end{array}$ & $\begin{array}{l}1.3 \\
2.6 \\
2.2 \\
1.6 \\
3.0 \\
1.1 \\
2.3 \\
1.5 \\
1.8 \\
1.1 \\
1.2 \\
= \\
= \\
- \\
- \\
-\end{array}$ & $\begin{array}{r}6.9 \\
12.4 \\
9.8 \\
7.2 \\
8.1 \\
8.0 \\
7.2 \\
5.2 \\
8.5 \\
5.6 \\
5.1 \\
= \\
= \\
- \\
- \\
-\end{array}$ & $\begin{array}{l}<1 / 4 \\
<1 / 4 \\
<1 / 4 \\
<1 / 4 \\
<1 / 4 \\
<1 / 4 \\
<1 / 4 \\
<1 / 4 \\
<1 / 4 \\
<1 / 4 \\
<1 / 4 \\
<1 / 4 \\
<1 / 4 \\
<1 / 4 \\
<1 / 4 \\
<1 / 4 \\
<1 / 4 \\
<1 / 4 \\
<1 / 4\end{array}$ \\
\hline \multicolumn{7}{|c|}{ Subacute disease, Group B1 } \\
\hline $\begin{array}{l}\text { Keto } \\
\text { Caleb } \\
\text { Rex } \\
\text { Quelle }\end{array}$ & $\begin{array}{l}\text { Death day } 14 \\
\text { Death day } 21 \\
\text { Death day } 8 \\
\text { Death day } 16\end{array}$ & $\begin{array}{l}40 \\
38 \\
28 \\
28\end{array}$ & $\begin{array}{l}125 \\
110 \\
150 \\
105\end{array}$ & $\begin{array}{l}0.6 \\
3.5 \\
1.0 \\
-\end{array}$ & $\begin{array}{l}3.0 \\
7.2 \\
4.6 \\
-\end{array}$ & $\begin{array}{l}1 / 40 \\
<1 / 4 \\
<1 / 4 \\
1 / 100\end{array}(1 / 20$ day 4$)$ \\
\hline \multicolumn{7}{|c|}{ Chronic disease, Group B2 } \\
\hline $\begin{array}{l}\text { Tally } \\
\text { Uta } \\
\text { Sol** } \\
\text { Thor** } \\
\text { Xerox } \\
\text { Chris } \\
\text { Fatal }\end{array}$ & $\begin{array}{l}\text { Death } 7 \text { mos. } \\
\text { Death } 5 \text { mos. } \\
\text { Survived indef. } \\
\text { Survived indef. } \\
\text { Survived } 7 \text { mos. } \\
\text { Survived } 8 \text { mos. } \\
\text { Survived } 8 \text { mos. }\end{array}$ & $\begin{array}{r}18 \\
17 \\
13 \\
17 \\
20 \\
10 \\
8\end{array}$ & $\begin{array}{r}58 \\
70 \\
106 \\
140 \\
170 \\
78 \\
83\end{array}$ & $\begin{array}{l}= \\
= \\
z\end{array}$ & $\begin{array}{l}E \\
= \\
=\end{array}$ & $\begin{array}{ll} & 1 / 100 \\
<1 / 4 & (1 / 320 \text { day } 5) \\
<1 / 4 & (1 / 500 \text { day } 4) \\
<1 / 4 \quad(1 / 100 \text { day } 4) \\
<1 / 4 \quad(1 / 36 \text { day } 5) \\
\quad 1 / 100 \\
1 / 100\end{array}$ \\
\hline
\end{tabular}

* Values listed are the maximum deviations from normal observed during illness.

‡ KAU, King-Armstrong units (normal 4-12).

\&U, Karman units (normal 20-50).

BSP control values: $\mathrm{Tm}=2.9 \pm 0.26 \mathrm{mg} / \mathrm{min} ; \mathrm{S}=12.8 \pm 1.18 \mathrm{mg} / \mathrm{mg} \%$.

If Values given are titers on the day of infection. Where antibody did not appear until after infection, the first positive titer and the day of detection are given in parentheses. Group A animals never had detectable antibody before death.

** Infected subcutaneously.

the acute disease had detectable levels of neutralizing antibody to the virus prior to or during the course of infection (Table II).

\section{B) Prolonged disease in the partially susceptible dog}

11 dogs had a distinctly different and more prolonged illness after experimental infection (Group $B$, Tables I and II). In four of these, death occurred in 8-21 days after infection, following what may be called a subacute course (Group B1). The remaining dogs survived up to 8 months af- ter infection with evidence of chronic hepatic disease (Group B2). In all 11 dogs with prolonged disease, low levels of antiviral antibody were detected in the serum at the time of infection, or appeared very early after infection.

1) Subacute disease. Keto is representative of the dogs with subacute disease. This dog appeared perfectly well between the 4th and 8th day after infection, at a time when fully susceptible animals died. There were no alterations in SGOT, serum alkaline phosphatase or BSP Tm or S. Then, toward the end of the 2nd wk after 

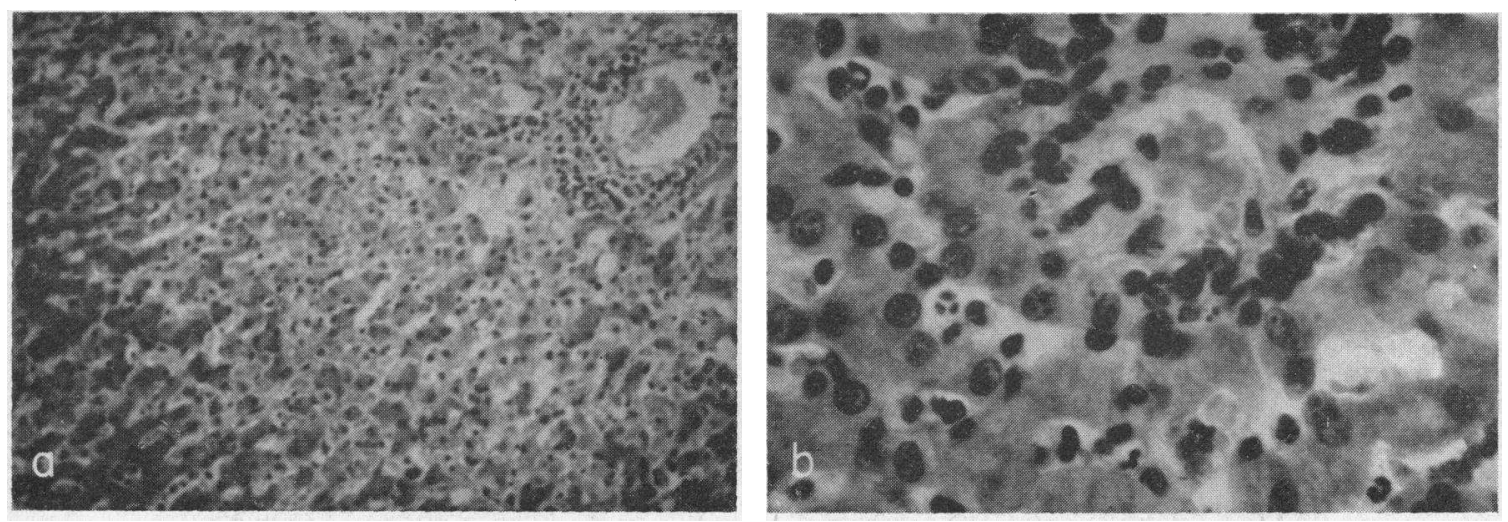

Fig. 4. Hepatic biopsy from Keto on the day of death (day 14). (a) Widespread hepatic necrosis with intense inflammatory response especially about a dilated central vein. Hematoxylin and eosin, $\times 100$. (b) Higherpower view showing the predominance of mononuclear cells and the absence of intranuclear inclusions. Hematoxylin and eosin, $\times 400$.

infection, the dog became clinically ill. On days 13 and 14 elevation of SGOT and marked depression of BSP S and Tm were found. The dog died on the 14th day. The preinfection serum from this animal contained antiviral antibody with a titer of $1 / 40$. Viremia was never detected.

Hepatic biopsies on the 5th day after infection revealed small foci of necrosis similar to that shown in Fig. 2. Virus was identified in these lesions by the presence of intranuclear inclusion bodies, and by specific staining with fluoresceinlabeled antiviral antibody. In addition to the usual polymorphonuclear leukocyte response, the necrotic foci contained significant numbers of lymphocytes and plasma cells. The sections in Fig. $4 a$ and $b$ were obtained on the 14 th day after infection, just before the death of the animal. Widespread, severe hepatic necrosis was found. In addition, dense collections of lymphocytes and related forms were found about central veins and in portal areas. In contrast to the situation in dogs dying with the acute disease, the presence of the virus was not demonstrated at death in Keto either by the finding of inclusion bodies or by the fluorescent antibody technique.

A similar subacute course was observed in three other animals (Caleb, Rex, Quelle) in which death occurred between 8 and 21 days after infection (Caleb appeared extremely ill and was sacrificed on the 21 st day). In each, severe hepatic necrosis with lymphocytes and plasma cells was found at postmortem examination, yet the virus could not be demonstrated by the above methods. In addition, each dog had low levels of neutralizing antibody before infection, or appearing early after infection. Clinical and biochemical data obtained in the animals with subacute disease are presented in Table II (Group B1). In general, the functional abnormalities found in the subacute illness resembled those described for the dogs with acute disease, except that they were delayed in appearance.

2) Chronic disease. Chronic hepatic damage was observed in seven dogs with low antibody titers who survived as long as 8 months after infection. Initially, there was minimal clinical or biochemical evidence of illness in these animals. However, biopsies during the 1 st wk after infection revealed small foci of hepatic necrosis with inclusion bodies and positive fluorescent staining indistinguishable from that seen in acute animals (Fig. 2). The animals survived this early phase and over the following months the evolution of chronic hepatic damage was observed. Fig. $5 a$ is from the 27 th day after infection in the dog Tally and shows one of the dense accumulations of lymphoid cells and plasma cells scattered throughout the liver. Fig. $5 b$ was obtained 2 months after infection in this dog and shows an enlarged portal area infiltrated with round cells and plasma cells. 5 months after infection chronic inflammatory infiltrates persisted and portal fibrosis was noted. Tally expired 7 months after infection, and at autopsy marked chronic inflammation and significant fibrosis were found (Fig. 6). Beyond the 10 th day after infection, virus was no longer iden- 

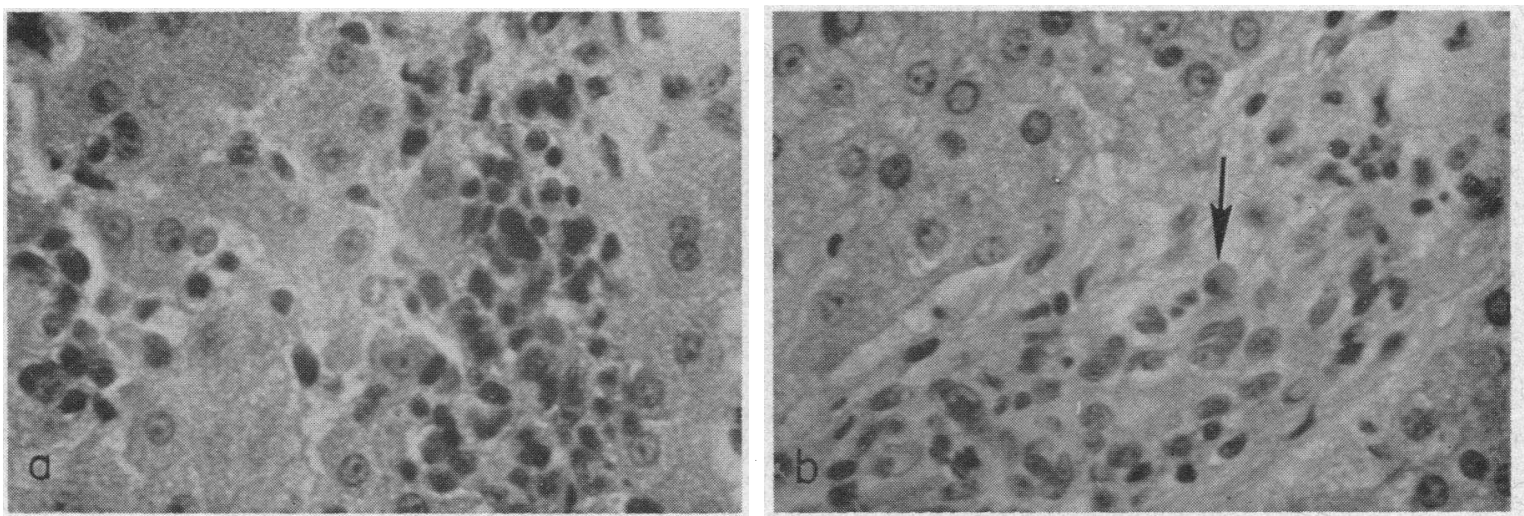

Fig. 5. (a) LiVER BIOPSY FROM TALLY ON 27TH DAY AFTER INFECTION SHOWING ONE OF THE COLLECTIONS OF LYMPhoid Cells sCattered Throughout the liver. Hematoxylin and eosin, $\times 400$. (b) Biopsy from Tally 2 months after infection showing an enlarged portal area infiltrated with mononuclear cells and plasma cells (arrow). Hematoxylin and eosin, $\times 400$.
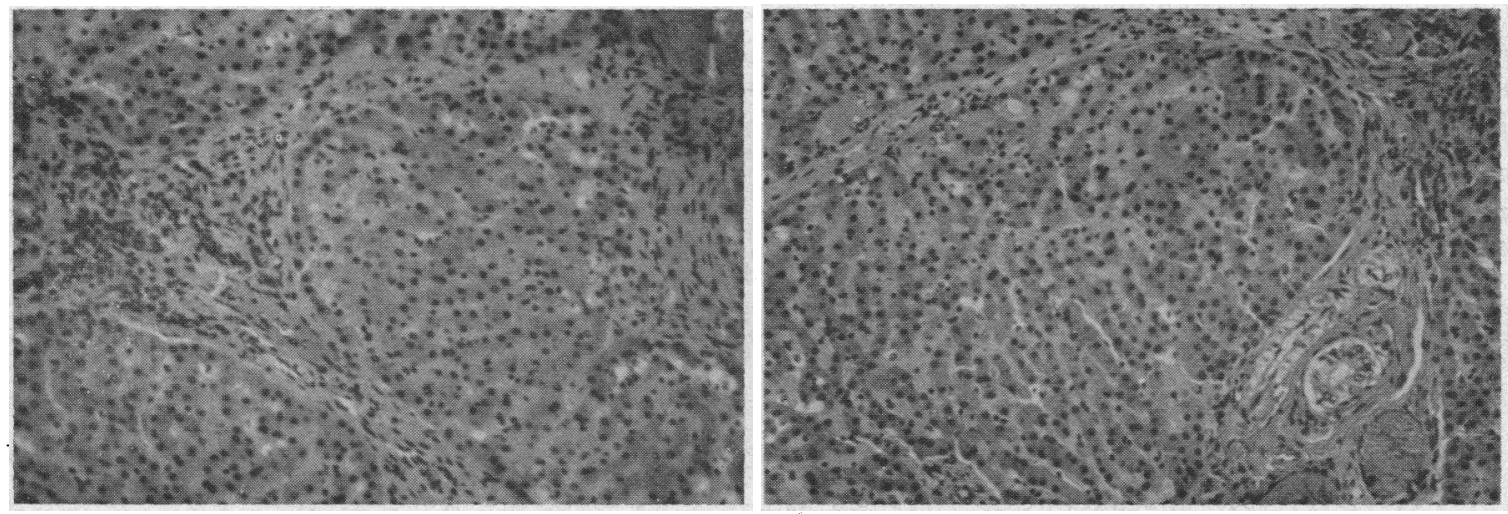

Fig. 6. Postmortem findings in TAlly, who died 7 Months After infection, Showing Marked Chronic inFLAMMATORY REACTION AND EXTENSIVE FIBRosis. Hematoxylin and eosin, $\times 100$.

tified in the hepatic lesions by the finding of inclusion bodies or by the fluorescent antibody technique.

The remaining six dogs in the chronic group demonstrated progressive development of similar hepatic changes on serial biopsy. One of them (Uta) died 5 months after infection with marked hepatic fibrosis. The others have survived a minimum of 7 months and continue to be studied. It is to be reemphasized that antiviral antibody titers between $1 / 4$ and $1 / 500$ were present in these dogs either at the time of infection or appeared quickly in 4-5 days after infection (Table II). As with the subacute animals, the presence of virus could not be demonstrated in the liver beyond the first 7-10 days after infection. Collection of functional data in this group was limited be- cause of belated recognition that the animals were ill.

\section{C) Observations in the nonsusceptible animal}

19 dogs (Group C, Table I) were infected and failed to develop any sign of disease. They appeared well clinically after infection; there was no alteration in SGOT, serum alkaline phosphatase, or BSP $\mathrm{Tm}$ or $\mathrm{S}$. The presence of the virus could not be demonstrated by the fluorescent antibody technique, and serial biopsies of the liver remained normal. These dogs all had neutralizing antibody to the canine hepatitis virus in the serum at the time of infection, usually with a titer greater than $1 / 500$. Thus, they appeared to have sufficient levels of antiviral antibody to be protected from infection. 
II) EXPERIMENTAL MODIFiCATION OF THE DisEASE

The observations described above on the occurrence of the subacute and chronic forms of hepatic disease after experimental infection were initially the results of chance encounters with partially immune dogs. When the apparent relation between low titers of antibody to the virus and prolonged forms of hepatitis was recognized, experiments were undertaken to reproduce and confirm these findings in a prospective fashion. This was done by passive administration of hyperimmune antiserum against the canine hepatitis virus to fully susceptible dogs. On the basis of the estimated blood volume of the dog and the titer of the antiserum, the amount of serum required to produce approximately a $1 / 50$ titer of antibody in the animal was calculated. The antiserum was administered intravenously, and 10-20 min later the animal was infected with the standard dose of virus. In the first eight attempts, the subacute disease pattern has been observed in three dogs and the chronic pattern has occurred in four, one of which died at 4 months. The remaining dog died on day 5 with typical acute hepatitis. In addition, a control group of five fully susceptible dogs not given antiserum was inoculated in the same manner with the same dose and preparation of virus, and all went on to die with typical actue hepatitis. The hepatic changes seen in the passively immunized animals duplicated the histologic findings already described. Thus, the subacute and chronic disease patterns observed in dogs passively immunized to the hepatitis virus before infection were indistinguishable from the patterns encountered in animals with partial natural immunity.

\section{Discussion}

The acute form of canine hepatitis observed in these studies was a fulminant, rapidly fatal infection in animals lacking an effective immune defense. The virus was first found in the Kupffer cells of the liver, suggesting that the infectious agent reached the liver by the blood stream, and was filtered out by cells of the reticuloendothelial system. Once in the Kupffer cells, the virus underwent rapid multiplication, with an explosive progression of hepatic damage. In contrast to the situation in the subacute and chronic diseases to be discussed below, there was an easily recognized correlation between the demonstrable presence of virus and the extent of hepatic necrosis. The degree of functional abnormalities correlated well in general with the severity of hepatic necrosis. The pathophysiologic factors responsible for death in these animals have not been well studied previously and are a subject of continuing investigation. However, it has been extensively shown by Rubarth (1) and others, and confirmed in our experience, that although the virus can be found throughout the body, the liver is the only site of major injury.

None of the 19 animals that succumbed to the fulminating acute form of hepatitis (Group A) had detectable antibody to the canine hepatitis virus in the serum either at the time of infection or during the brief illness. The absence of neutralizing antibody was quite consistent with rapid progression of the infection and death of the animal before an effective immune defense could be raised. At the other extreme, the dogs that failed to develop any sign of illness (Group C) were always found to have relatively high levels of neutralizing antibody to the virus in the serum at the time of infection. No exception to these observations has been encountered and, indeed, this would be the expected effect of specific immunity to an infectious agent on the outcome of the infection.

The animals in Group B, however, demonstrate an unexpected and untoward effect of host immunity on the course of the disease. These dogs had low titers of antiviral antibody at the time of infection, or were able to produce antibody rapidly in the first 4-6 days of illness. They survived the initial phase but developed definite hepatic damage, sometimes leading to death, despite the presence of antibody to the infectious agent. Thus, partial immunity to the virus seemed to have a clear, though unexplained, correlation with the development of persistent hepatic injury. This observation was strongly supported by the successful reproduction of the subacute and chronic forms of hepatitis in seven of the eight dogs passively immunized to the virus.

Certain notable features characterize the subacute and chronic disease patterns. Although the $\mathrm{ICH}$ virus could be identified in small necrotic 
foci in the liver in the first few days after infection, the rapid progression of hepatic necrosis seen in the acute disease did not occur. Instead, the virus seemed to disappear, at least in so far as it could be detected by the techniques available. In contrast to Group A animals, the virus could not be found in the animals even when severe hepatic necrosis and death occurred. Whether the disappearance of the virus is real or only apparent is not yet clear. The absence of intranuclear inclusion bodies and the negative fluorescent antibody test do not completely rule out the persistence of virus in an incomplete or atypical form. Attempts have been made to recover virus from the liver in tissue culture on 41 different occasions in nine dogs with positive results only in the 1st wk after infection. Additional recovery attempts are currently underway to extend these findings.

Despite the apparent absence of the virus, hepatic damage continued in both the subacute and chronic animals. The predominance of lymphoid elements was an outstanding feature. In the subacute disease, severe and extensive hepatic necrosis ensued, leading to death of the animal. The hepatic damage involved the entire liver lobule, and lymphocytes, monocytes, and plasma cells were scattered profusely in the sinusoids and in dense accumulations about central veins and in portal tracts. In the chronic disease, the animals survived at least for several months with evidence of persistent hepatic injury. In the early weeks focal collections of lymphoid cells were found throughout the liver, and in later stages these chronic inflammatory cells were localized in portal areas in association with fibrosis. The finding of portal fibrosis in the later stages of the chronic disease is of note. In some instances, fibrosis was quite definite and had interlobular extensions. However, severe distortion of hepatic architecture and lobular regeneration were not prominent findings, nor was evidence of portal hypertension available. What is noteworthy is the finding of a chronic, prolonged form of hepatic damage with portal fibrosis as one of the outstanding features.

The source of the antiviral antibody in the animals with partial immunity is of some interest. Carmichael et al. (14) found the half-life of maternal neutralizing antibody to the $\mathrm{ICH}$ virus in young beagle puppies was 8.6 days. Thus, the age of the animals used in this study (12-20 wk) should have allowed for the disappearance of the bulk of maternal antibody. However, it is conceivable that occasional puppies were encountered from sufficiently high titered mothers to provide for the persistence of low titers of antiviral antibody in the offspring even at 5 months of age. Unfortunately, maternal serum was not available for titration. Also, it is possible that some of the animals had previous unrecognized natural infections. Perhaps the dogs that lacked antibody initially, but developed titers rapidly, were showing an anamnestic response. Another possible source of low levels of antibody may lie in the known antigenic relationship of the ICH adenovirus to some of the human adenoviruses. Carmichael and Baker (15) have made the interesting observation that dogs inoculated intranasally with adenovirus type 4 developed neutralizing antibodies following an asymptomatic infection. When such dogs were later inoculated with $\mathrm{ICH}$ virus, a secondary or anamnestic type of neutralizing antibody response occurred to both viral antigens, and antibodies persisted for at least 340 days. Thus, it is conceivable that our animals had been previously exposed to a human adenovirus while in isolation and thus sensitized to subsequent inoculation with $\mathrm{ICH}$ virus. The presence of small amounts of antibody to the virus may simply permit the animal to survive the acute stages of infection, and then some other pathologic process supervenes to produce further hepatic injury. However, it is not at all clear why a small amount of antibody should not simply suppress or attenuate the infection with eventual recovery, rather than predispose to continuing liver damage.

Although there is ample precedent for the persistence of virus in a host's tissues with production of latent or inapparent infection, in such instances the virus is demonstrable at sites of cell damage (16-18). Also, virus can be identified easily in the liver in other types of viral hepatitis (18-20). It would seem unlikely, therefore, that the canine hepatitis virus could produce the liver damage seen in the Group B animals without being easily detected. Conceivably, some other latent agent, such as herpes virus, could be activated by the initial infection with $\mathrm{ICH}$ virus and then take over the cytopathic process in later stages of the disease. Carmichael et al. have described a fatal viral disease of newborn pups 
in which the etiologic agent was identified as a herpes virus $(21,22)$. Although this virus was found to cause severe illness and death only in very young pups (1-3 wk old), the possibility of latent infection and subsequent reactivation, as recognized with other herpetic infections, remains to be evaluated.

The possible role of an immunologic process in the pathogenesis of chronic hepatic damage has received prominent consideration in human hepatitis, and is suggested in the studies reported here by the striking collections of round cells and plasma cells seen in biopsies from dogs with subacute and chronic disease. Antibodies against human or animal liver antigens in acute hepatitis and other liver diseases have been demonstrated by a number of investigators (23). However, these antibodies have not been clearly shown to be specific for liver antigen only, and it is difficult to establish what role, if any, such "autoantibodies" play in the actual pathogenesis of hepatic damage. Perhaps more pertinent to the present studies is the possibility that circulating antigenantibody complexes may accentuate necrosis in the liver initiated by the virus. Paronetto and Popper (24) have demonstrated the uptake of antigen-antibody complexes by mildly damaged liver cells of mice when the Kupffer cells which normally take up such complexes failed to do so. This resulted in marked increase in the extent of hepatocellular damage, and suggested that hepatic deposition of cytotoxic immune complexes may magnify preexisting minimal hepatic alterations. In light of this work it is interesting to note that about 1-3 wk after recovery from infectious canine hepatitis, some dogs develop an intense anterior uveitis with corneal opacification (even when infected by other than the intraocular route). Carmichael (25) showed that this reaction has the pathologic characteristics of Arthus-type hypersensitivity and occurred only when viral antigen and specific antibody were present concurrently in the eye tissues. The entire phenomenon was reproduced by intraocular inoculations of $\mathrm{ICH}$ virus-antibody complexes. Thus, it is conceivable, especially in dogs with subacute hepatitis, that virus-antibody complexes could be responsible for the accentuation and extension of liver damage initiated by the virus.
The experiments described in this report provide new information on the pathogenesis of virus-induced hepatic injury in the dog. They also demonstrate the potentially deleterious effect of partial immunity to the infectious agent on the course of the disease. The possible relevance of these findings to viral hepatitis in man raises interesting questions which cannot be resolved at the present time. Despite certain similarities, hepatitis in man and in the dog are different diseases caused by different agents. No attempt is intended here to equate findings in the dog with the situation in man. However, observations on the pathogenesis of virus-induced hepatic injury in the dog may provide a different point of view on the problem of human hepatitis, and perhaps suggest fresh experimental approaches.

\section{References}

1. Rubarth, S. 1947. An acute virus disease with liver lesion in dogs (hepatitis contagiosa canis). A pathologico-anatomical and etiological investigation. Acta Path. Microbiol. Scand., Suppl. 69 : 9.

2. Cabasso, V. J., M. R. Stebbins, T. W. Norton, and H. R. Cox. 1954. Propagation of infectious canine hepatitis virus in tissue culture. Proc. Soc. Exptl. Biol. Med. 85 : 239.

3. Fieldsteel, A. H., and J. B. Emery. 1954. Cultivation and modification of infectious canine hepatitis virus in roller tube cultures of dog kidney. Proc. Soc. Exptl. Biol. Med. 86: 819.

4. Cabasso, V. J., M. R. Stebbins, and J. M. Avampato. 1958. A bivalent live virus vaccine against canine distemper (CD) and infectious hepatitis ( $\mathrm{ICH})$. Proc. Soc. Exptl. Biol. Med. 99: 46.

5. Burgher, J. A., J. A. Baker, S. Sarkar, V. Marshall, and J. H. Gillespie. 1958. Evaluation of a combined vaccine consisting of modified canine distemper virus and modified infectious canine hepatitis virus for simultaneous immunization of dogs. Cornell Vet. 48: 214.

6. Kapsenberg, J. G. 1959. Relationship of infectious canine hepatitis virus to human adenovirus. Proc. Soc. Exptl. Biol. Med. $101: 611$.

7. Heller, L. A., and C. R. Salenstedt. 1960. Onesided immunologic relation between adenovirus and infectious canine hepatitis antigens. Virology. $11: 640$.

8. Cabasso, V. J. 1962. Infectious canine hepatitis virus. Ann. N. Y. Acad. Sci. $101: 498$.

9. Preisig, R., R. Williams, J. Sweeting, and S. E. Bradley. 1966. Changes in sulfobromophthalein transport and storage by the liver during viral hepatitis in man. Am. J. Med. 40:170 
10. Bodian, D. 1956. Simplified method of dispersion of monkey kidney cells with Trypsin. Virology. 2: 575 .

11. Carmichael, L. E., G. E. Atkinson, and F. D. Barnes. 1963. Conditions influencing virus-neutralization tests for infectious canine hepatitis antibody. Cornell Vet. 53 : 369.

12. Finney D. J. 1952. Statistical method in biological assay. Hafner Publishing Company, New York. Exptl. Biol. Med. 109: 677.

13. Rinderknecht, H. 1962. Ultra-rapid fluorescent labelling of proteins. Nature. 193: 167.

14. Carmichael, L. E., D. S. Robson, and F. D. Barnes. 1962. Transfer and decline of maternal infectious canine hepatitis antibody in puppies. Proc. Soc. Exptl. Biol. Med. 109: 677.

15. Carmichael, L. E., and J. A. Baker. 1962. Secondary serological response to infectious canine hepatitis virus produced by adenovirus type 4 . Proc. Soc. Exptl. Biol. Med. $109: 75$.

16. Hotchin, J. 1962. The biology of lymphocytic choriomeningitis infection: virus-induced immune disease. Cold Spring Harbor Symp. Quant. Biol. 27: 479.

17. McNair Scott, T. F., and T. Tokumaru. 1965. The herpesvirus group. In Viral and Rickettsial Infections of Man. F. L. Horsfall and I. Tamm, editors. J. B. Lippincott Co., Philadelphia. 4th edition. 892.

18. Mims, C. A. 1959. The response of mice to large intravenous injections of ectromelia virus. II. The growth of virus in the liver. Brit. J. Exptl. Pathol. 40: 543.

19. Tigertt, W. D., T. O. Berge, W. S. Gochenour, C. A. Gleiser, W. C. Eveland, C. V. Bruegge, and H. F. Smetana. 1960. Experimental yellow fever. Trans. N. Y. Acad. Sci. $22: 323$.

20. Ruebner, B., and K. Miyai. 1962. The Kupffer cell reaction in murine and human viral hepatitis, with particular reference to the origin of acidophilic bodies. Am. J. Pathol. 40: 425.

21. Carmichael, L. E., R. A. Squire, and L. Krook. 1965. Clinical and pathologic features of a fatal viral disease of newborn pups. Am. J. Vet. Res. 26: 803 .

22. Carmichael, L. E., J. D. Strandberg, and F. D. Barnes. 1965. Identification of a cytopathogenic agent infectious for puppies as a canine herpesvirus. Proc. Soc. Exptl. Biol. Med. 120: 644.

23. Deinhardt, F., and A. W. Holmes. 1965. Epidemiology and etiology of viral hepatitis. In Progress in Liver Diseases. H. Popper and F. Schaffner, editors. Grune \& Stratton, Inc., New York. 2: 373.

24. Paronetto, F., and H. Popper. 1965. Aggravation of hepatic lesions in mice by in vivo localization of immune complexes (Auer Hepatitis). Am. J. Pathol. 47 : 549.

25. Carmichael, L. E. 1965. The pathogenesis of ocular lesions of infectious canine hepatitis. Pathol. Vet. (Basel). 2: 344 . 